\title{
PRAYING TO THE HOLY SPIRIT IN EARLY CHRISTIANITY $^{1}$
}

\author{
Boris Paschke
}

\begin{abstract}
Summary
This article studies praying to the Holy Spirit in early Christianity of the first three centuries $A D$. The relevant primary sources are presented and interpreted. While the New Testament remains silent on the topic, some early Christian texts from the Second and Third Centuries $A D$ (i.e. writings of Tertullian and Origen as well as the Acts of John and Acts of Thomas) testify that the idea and practice of addressing the Holy Spirit in prayer (either alone or together with Jesus Christ) existed in early Christianity. However, the paucity of express early Christian quotations of or references to prayers to the Holy Spirit suggests that praying to the Holy Spirit was not widespread but rather remained an exception in early Christianity.
\end{abstract}

\section{Introduction}

Today, prayer to the Holy Spirit is practised not only in charismatic/ Pentecostal Christian communities ${ }^{2}$ but also in more 'mainstream' churches within the Catholic ${ }^{3}$ and Protestant traditions. ${ }^{4}$ The Common

1 An earlier version of this paper was read on 3 November 2012 in Wycliffe Hall (Oxford University) in the framework of the conference 'Bridging the Gap between Bible and Doctrine: The Holy Spirit' (1 to 4 November 2012) that was jointly organised by the Evangelische Theologische Faculteit Leuven, the Vrije Universiteit Amsterdam, and Wycliffe Hall.

2 Cf. e.g. the important role that the prayer 'Holy Spirit, come' plays in church services of the Vineyard Christian Fellowship: Bill Jackson, The Quest for the Radical Middle: A History of the Vineyard (Cape Town: Vineyard International Publishing, 2000): 73; John Wimber with Kevin Springer, Power Healing (San Francisco, CA: Harper \& Row, 1987): 212.

3 Cf. Barbara Busowietz, 'Der Heilige Geist in unseren Gebeten und charismatischen Gebetsgruppen', Lebendige Seelsorge 48 (1997): 143. 
Worship of the Church of England, for instance, suggests the English translation of the ninth-century Latin hymn Veni creator Spiritus as preparation for the celebration of the Eucharist. The first verse of this hymn 'Come, Holy Ghost' reads:

Come, Holy Ghost, our souls inspire,

And lighten with celestial fire;

Thou the anointing Spirit art,

Who dost thy sevenfold gifts impart. ${ }^{5}$

The goal of the present article is to study the early Christian roots of directly addressing the Holy Spirit in prayer. To date, scholarship largely neglected the issue of praying to the Holy Spirit in early Christianity. Various studies have been devoted to the 'spirit epicleses' in chapters 27 and 50 of the third-century apocryphal Acts of Thomas (ATh). ${ }^{6}$ With regard to praying to the Holy Spirit in early Christianity as a whole, however, a comprehensive overview in either article or book form is still a desideratum. This short study is thus a first step to fill this gap in research. In the following, the relevant early Christian texts of the first three centuries AD are presented and interpreted.

\section{Early Christian Interpretation of Ezekiel 37:9}

According to some scholars, the Holy Spirit is directly addressed in Ezekiel 37:9. Lamar Eugene Cooper comments on this verse, 'It clearly was God's Spirit who was to give breath to these corpses, and Ezekiel was given the extraordinary task of summoning him. ${ }^{7}$ Likewise, Heinz Kruse states that Ezekiel 37:9 is the only verse in the whole Bible

4 Cf. Geoffrey Wainwright, 'Veni, Sancte Spiritus: The Invocation of the Holy Spirit in the Liturgies of the Churches' in The Holy Spirit, the Church, and Christian Unity: Proceedings of the Consultation Held at the Monastery of Bose, Italy (14-20 October 2002), ed. D. Donnelly, A. Denaux, and J. Famerée (Bibliotheca Ephemeridum Theologicarum Lovaniensum 181; Leuven: Leuven University Press / Peeters, 2005): $303-26$.

5 Common Worship: Services and Prayers for the Church of England (London: Church House Publishing, 2000): 161.

6 Cf. Susan E. Myers's recent monograph Spirit Epicleses in the Acts of Thomas (Wissenschaftliche Untersuchungen zum Neuen Testament II/281; Tübingen: Mohr Siebeck, 2010) as well as the literature referred to in this book.

7 Lamar Eugene Cooper, Ezekiel (The New American Commentary 17; Nashville, Tennessee: Broadman \& Holman, 1994): 324. 
where the Holy Spirit is directly addressed (with an imperative). ${ }^{8}$ Kruse even goes so far as to state that Ezekiel 37:9 without doubt influenced the formulation of the spirit epiclesis in ATh 27.9

According to the New Revised Standard Version (NRSV) of the Bible, Ezekiel 37:9 reads as follows: 'Then he [the Lord] said to me [Ezekiel], "Prophesy to the breath, prophesy, mortal, and say to the breath: Thus says the Lord GOD: Come from the four winds, $\mathrm{O}$ breath, and breathe upon these slain, that they may live." According to both the Hebrew Bible and the Septuagint, the prophet is clearly supposed to utter an imperative, i.e. בּּ ִּ rendering the ambiguous Hebrew word רחוּ (the Greek $\pi v \varepsilon \tilde{y} \mu \alpha$ is equally ambiguous) with 'breath', the NRSV translators suggest that the imperative is not addressed to God's Holy Spirit (as stated by both Cooper and Kruse) but rather to some kind of wind/breath that might not directly stem from God. The majority of commentators on Ezekiel 37:9 opt for this second interpretation. Walther Zimmerli, for instance, states that in Ezekiel 37:9 'it is not a רוח ("spirit") which comes from God. Rather, this possibility of life seems to be regarded as something which pervades the whole world, which now blows upon the human corpses like a wind in order to transform them into living creatures. ${ }^{10}$ In the framework of the present article, the exegetical question whether

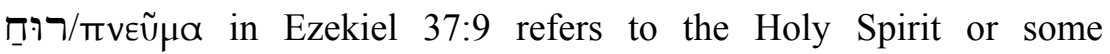
wind/breath cannot be solved.

It is, however, crucial to learn if/how this question was answered in early Christian literature. The New Testament does not refer to Ezekiel 37:9. Of all the patristic texts indicated in the Biblia Patristica with regard to Ezekiel 37:9,11 only a passage from Ambrose's fourth-century treatise on the Holy Spirit is somewhat instructive with regard to the question raised above. In De Spiritu Sancto III 19:149-150, Ambrose

8 Heinz Kruse, 'Zwei Geist-Epiklesen der syrischen Thomasakten', Oriens Christianus 69 (1985): 36: 'Die einzige Stelle, wo der Geist Gottes in der H1. Schrift direkt (mit Imperativ) angeredet wird, ist Ez 37,9.'

9 Kruse, 'Zwei Geist-Epiklesen', 36: 'Es kann kaum zweifelhaft sein, daß Ez 37,9 bei der Formulierung dieser Geistepiklese bestimmend mitgewirkt hat.'

10 Walther Zimmerli, Ezekiel 2: A Commentary on the Book of the Prophet Ezekiel Chapters 25-48 (Hermeneia; Philadelphia, PA: Fortress Press, 1983): 261; cf. Moshe Greenberg, Ezechiel 21-37 (Herders Theologischer Kommentar zum Alten Testament; Freiburg: Herder, 2005): 459.

11 The Biblia Patristica has been consulted via the 'Biblindex' search engine provided on www.biblindex.mom.fr. [accessed 29 November 2012] The Early Christian Commentary on Scripture does not provide any comments on Ezek. 37:9. 
argues that Ezekiel 37:9 refers to the Holy Spirit. ${ }^{12}$ However, Ambrose does not label the prophet Ezekiel's words to the Holy Spirit a prayer.

\section{New Testament}

According to the New Testament, prayer is and should be usually addressed to God the Father (cf., e.g., Matt. 6:9; Luke 11:2). Even though the New Testament contains a few (references to) prayers to Jesus (i.e. John 14:14; Acts 7:59-60; 1 Cor. 16:22; 2 Cor. 12:8; Rev. 22:20), its overall teaching is that the Father should be addressed in the name of Jesus. Further, the New Testament teaches that the Holy Spirit helps the believer to address the Father (Rom. 8:26; Gal. 4:6). However, in contrast to Jesus, the Holy Spirit is never expressly addressed in prayer in the New Testament. Likewise, express references to prayers to the Holy Spirit are absent from the New Testament.

In the appendix to his work Hymni ecclesiastici, Georg Cassander (1513-1566) tries to demonstrate that in accordance with the theological concept of appropriation, some of the New Testament prayers to the 'Lord' are specifically addressed to the Holy Spirit, namely the prayers to the Lord who knows the hearts and to the Lord who elects people for ministry in the church (cf. Acts 1:24). ${ }^{13}$

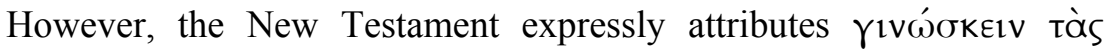
kapóias not to the Holy Spirit, but to God the Father (Luke 16:15; 1 Thess. 2:4; Rom. 8:27) and Jesus (Rev. 2:23). It can thus be maintained that - like the Old Testament- the New Testament does not contain any (reference to a) prayer to the Holy Spirit. ${ }^{14}$

12 St. Ambrose, Select Works and Letters (A Select Library of Nicene and PostNicene Fathers of the Christian Church 10; Edinburgh: T\&T Clark, 1989): 156.

13 Cf. Peter Walter, 'Das Gebet zum Heiligen Geist und der in uns betende Heilige Geist: Gedanken zu einer am biblischen und liturgischen Zeugnis orientierten Trinitätstheologie' in Seelsorge in der Kraft des Heiligen Geistes, ed. Philipp Müller und Hubert Windisch (FS Weihbischof Paul Wehrle; Freiburg i. Br.: Herder, 2005): 235-36.

14 Kruse, 'Zwei Geist-Epiklesen', 36: 'Die einzige Stelle, wo der Geist Gottes in der Hl. Schrift direkt (mit Imperativ) angeredet wird, ist Ez 37,9.' 


\section{Tertullian}

Tertullian's texts that are relevant for the study of early Christian prayer to the Holy Spirit come from De oratione (AD 198-200) and De baptismo (AD 200-206) and thus from works written before his conversion to Montanism between AD 207 and 213. In De oratione 12, Tertullian states,

And not from anger only, but from all and every perturbation of mind, ought the intensity of prayer to be free, being sent forth from such a spirit as is that Spirit to whom it is sent forth. For a defiled spirit can receive no recognition from holy Spirit [ $\langle a\rangle$ spiritu sancto $]$ - nor sad from glad, nor fettered from free. No man opens his door to an opponent, no man lets in anyone but his like. ${ }^{15}$

Since in Latin, there is no article, the phrase spiritu sancto is ambiguous and could refer to the Holy Spirit (i.e. the third person of the Trinity) or to the triune God as being a holy spirit (cf. John 4:24). This ambiguity is reflected in the various translations of De oratione 12. While some translators render spiritu sancto as 'the Holy Spirit' (with a capital ' $\mathrm{H}$ '), ${ }^{16}$ others agree with the above quoted translation of Ernest Evans and render the phrase as 'holy Spirit' (with a small ' $h$ '). ${ }^{17}$ Evans comments, "Holy Spirit" throughout this passage, as often in Tertullian, means God, without distinction of Persons.' ${ }^{18}$ For the sake of completeness it should be mentioned that the insertion of the

15 Ernest Evans, ed., Tertullian's Tract on the Prayer: The Latin Text with Critical Notes, an English Translation, an Introduction, and Explanatory Observations (London: S.P.C.K., 1953): 16-17.

16 Tertullian, Disciplinary, Moral and Ascetical Works (tr. by Rudolph Arbesmann et al. [The Fathers of the Church 40; New York, NY: Fathers of the Church, 1959]: 169); cf. Tertullians private und katechetische Schriften (tr. H. Kellner [Bibliothek der Kirchenväter 7; Kempten/München: Kösel, 1912]: 258: 'bei dem Heiligen Geiste').

17 Tertullian's Treatises Concerning Prayer, Concerning Baptism (tr. Alexander Souter [Translations of Christian Literature; London: Society for Promoting Christian Knowledge, 1919): 29; Tertullian, 'On Prayer' in The Ante-Nicene Fathers, vol. 3, ed. Alexander Roberts and James Donaldson (Edinburgh: T\&T Clark, 1993): 685; On the Lord's Prayer: Tertullian, Cyprian, Origen (tr. Alistair Stewart-Sykes [Popular Patristics Series; Crestwood, NY: St Vladimir's Seminary Press, 2004]: 50); Tertullian, De baptismo / De oratione (tr. Dietrich Schleyer [Fontes Christiani 76; Turnhout: Brepols, 2006]: 241: 'von einem reinen Geist'); Tertullianus, De oratione: Critische uitgave met prolegomena, vertaling en philologisch-exegetisch-liturgische commentaar, ed. II. Latin Texts (1919); G. F. Diercks (Bussum: Paul Brand, 1947): 23: 'een heilige geest'.

18 Evans, Tertullian's Tract on the Prayer, 52. 
preposition $a$ and thus the ablative of personal agency ${ }^{19}$ makes sense not only in a definite reading ${ }^{20}$ but also in an indefinite understanding of spiritu sancto. Evans states, 'The insertion of the preposition before spiritu sancto seems justified by its occurrence later in the sentence. In any case we should have wondered at its omission, for "spirit" to Tertullian is never less than personal. ${ }^{21}$ By way of conclusion, with regard to early Christian prayer to the Holy Spirit, De oratione 12 is a relevant text. Because of its ambiguity, however, it remains unclear whether Tertullian here refers to prayer to the third person of the Trinity at all. The following text of Tertullian is less ambiguous.

In his work De baptismo, Tertullian describes the procedure of a baptismal service. After he has referred to the baptism itself and the anointing of the one baptised with oil (cf. De baptismo 7), he continues in chapter 8: Dehinc manus imponitur per benedictionem advocans et invitans spiritum sanctum..$^{22}$ Evans translates this as follows: 'Next follows the imposition of the hand in benediction, inviting and welcoming the Holy Spirit.' ${ }^{23}$ By rendering sanctum with the capitalised 'Holy', Evans indicates that he understands spiritum sanctum in terms of the Holy Spirit as the third person of the Trinity. All other translations that have been consulted in the present research agree with Evans's interpretation. ${ }^{24}$ That the Holy Spirit as third person of the Trinity is meant here is suggested by De baptismo 6 where a clear differentiation between 'the Father and the Son and the Holy Spirit' (pater et filius et spiritus sanctus) is made. Because the Holy Spirit is 'invoked' (advocans) and 'invited' (invitans), the rite that

19 Cf. John F. Collins, A Primer of Ecclesiastical Latin (Washington, DC: The Catholic University of America Press, 1985): 58: 'The ablative case may be used with a personal noun to express the doer or agent of a verb in the passive voice. The preposition $\bar{a}(a b, a b s)$ is always used in this construction.'

20 Cf. however, Tertullianus, De oratione (ed. Diercks), 144: 'spiritu sancto [is] hier niet ... de H. Geest, de Derde Persoon van de H. Drieëenheid (zo Kellner), maar de heilige geest Gods, de (sit venia verbo) geestesgesteldheid Gods. Gelenius' tekstverandering (a spiritu) is dus wederom willekeurig en onnodig.'

21 Evans, Tertullian's Tract on the Prayer, 52.

22 Ernest Evans, ed., Tertullian's Homily on Baptism: The Text Edited with an Introduction, Translation and Commentary (London: S.P.C.K., 1964): 16.

23 Evans, Tertullian's Homily on Baptism, 17.

24 Tertullian, 'On Baptism' in The Ante-Nicene Fathers, vol. 3, ed. Alexander Roberts and James Donaldson (Edinburgh: T\&T Clark, 1993): 672; Tertullian's Treatises (ed. Souter), 55; Tertullien, Traité du baptême, ed./tr. R. P. Refoulé and M. Drouzy (Sources Chrétiennes 35; Paris: Cerf, 2002): 'l'Esprit-Saint'; Tertullians private und katechetische Schriften (tr. Kellner), 283: 'der Heilige Geist'. 
Tertullian describes can be considered an epiclesis in the sense of the following definition provided by Paul Bradshaw in The New Westminster Dictionary of Liturgy and Worship: 'A Greek word meaning "invocation", which can be used in a general sense to refer to any prayer invoking God to act, but is more often restricted to a specific calling upon the Holy Spirit, especially with the eucharistic prayer. Very early forms of epiclesis were addressed directly to the Spirit (or sometimes to the Logos) in the imperative: "Come". 25 Tertullian's description probably reflects the liturgical practice of the early church in North Africa. Caroline Johnson states: 'He [Tertullian] does not provide us with a text of the invocation, but at least we know that it was part of the rite he knew.'26

\section{Origen}

In the fifteenth chapter of his work De oratione (AD 233-234), Origen states the following rule regarding the addressee of Christian prayer: 'But if we give heed to what prayer properly is, surely prayer is to be addressed to no man born of woman, not even to Christ himself, but to the God and Father of all alone, to whom even our Saviour himself prayed ... and to whom he teaches us to pray.' 27

However, other writings of Origen contain exceptions to this rule. Origen not only prays to Christ (e.g. prayer to Jesus the footwasher in the fifth homily on Isaiah) ${ }^{28}$ but also encourages prayer to the Holy Spirit. At the beginning of his homilies on Leviticus (AD 238-244) which are only available in the Latin translation of Rufinus, he states:

Thus, the Lord himself, the Holy Spirit himself must be entreated by us [Ipse igitur nobis Dominus, ipse sanctus Spiritus deprecandus est] to

25 Paul Bradshaw, 'Epiclesis' in The New Westminster Dictionary of Liturgy and Worship, ed. Paul Bradshaw (Louisville, KY / London: Westminster John Knox Press, 2002): 166.

26 Caroline Johnson, 'Ritual Epicleses in the Greek Acts of Thomas' in The Apocryphal Acts of the Apostles: Harvard Divinity School Studies, ed. François Bovon et al. (Religions of the World; Cambridge, MA: Harvard University Press, 1999) : 17778.

27 Origen's Treatise on Prayer: Translation and Notes with an Account of the Practice and Doctrine of Prayer from New Testament Times to Origen, tr. by Eric George Jay (London: S.P.C.K., 1954): 126-27.

28 Angela Russell Christman, 'Origen's Prayer to Jesus the Footwasher' in Prayer from Alexander to Constantine: A Critical Anthology, ed. Mark Kiley et al. (London: Routledge, 1997): 304-308. 
remove every cloud and all darkness which obscures the vision of our hearts hardened with the stains of sins in order that we may be able to behold the spiritual and wonderful knowledge of his Law, according to him who said, 'Take the veil from my eyes and I shall observe the wonders of your Law' (Orig. Hom. Lev. I 1). ${ }^{29}$

In this passage, Origen expressly mentions the Holy Spirit (sanctus Spiritus) as addressee of prayers that ask for understanding of the biblical text. However, in the framework of the present article, it is crucial to examine whether (1) the sanctus Spiritus is understood as an equivalent to Dominus and thus is considered the sole addressee of the respective prayers; or (2) the sanctus Spiritus is addressed 'only' in addition to another person of the Trinity (i.e. the Father or Christ) who is called Dominus.

The following words that immediately precede the above quoted passage shed light on the issue:

Therefore, let us fall, if it is necessary, into your detractions so long as the Church, which has already turned to Christ the Lord [ad Christum iam Dominum], may know the truth of the Word which is completely covered under the veil of the letter. For thus the Apostle said, 'if anyone turns to the Lord [ad Dominum], the veil will be removed; for where the spirit of the Lord [Spiritus Domini] is, there is freedom. ${ }^{30}$

Here Origen quotes 2 Corinthians $3: 16-17,{ }^{31}$ a passage that contains a reference to Exodus 34:34 and that reads as follows: '[B]ut when one turns to the Lord [mpòs kúpiov], the veil is removed. Now the Lord is

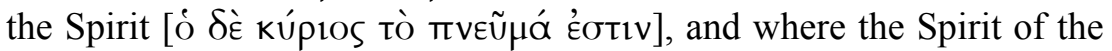
Lord [tò $\pi v \varepsilon \tilde{v} \mu \alpha$ kupíou] is, there is freedom.' ${ }^{32} \mathrm{~A}$ comparison between the wording of the New Testament and that of Origen reveals that Origen omits the phrase 'the Lord is the Spirit' (ò $\delta \dot{\varepsilon}$ kúpios tò

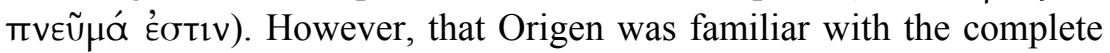

29 English: Origen, Homilies on Leviticus 1-16, tr. Gary Wayne Barkley (The Fathers of the Church 83; Washington, DC: The Catholic University of America, 1990): 30; Latin: Origène, Homélies sur le Lévitique, Tome I, Homélies I-VII, Texte Latin, introduction, traduction et notes par Marcel Borret (Sources Chrétiennes 286; Paris: Les éditions du cerf, 1981): 70.

30 English: Origen, Leviticus (tr. Barkley), 30; Latin: Origène, Lévitique (tr. Borret), $68-70$.

31 Cf. Margaret E. Thrall, A Critical and Exegetical Commentary on the Second Epistle to the Corinthians, vol.1, Introduction and Commentary on II Corinthians IVII (The International Critical Commentary; Edinburgh: T\&T Clark, 1994): 278-82. In an excursus, Thrall provides an excellent overview of the exegetical discussion regarding this passage.

32 English: NRSV; Greek: Novum Testamentum Graece, 28th edition. 
wording of 2 Corinthians 3:17 becomes obvious later on in his homilies on Leviticus, in Hom. Lev. IV 1,33 where he writes, "What is "the Lord"? Let the Apostle respond to you and learn from him that "the Lord is Spirit" Apostolus tibi respondeat et ab ipso disce quia Dominus Spiritus est' ${ }^{34}$

In the above quoted passage, Origen understands the Lord in 2 Corinthians 3:16 and Exodus 34:34 (ad Dominum) as the Lord Jesus Christ (ad Christum iam Dominum). This suggests that for Origen, Dominus in 2 Corinthians 3:17 also refers to the Lord Jesus Christ. Thus, when he then goes on to state that 'the Lord himself ... must be entreated by us [Ipse igitur nobis Dominus ... deprecandus est]', he probably identifies 'the Lord himself' (Ipse ... nobis Dominus) with

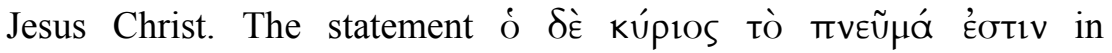
2 Corinthians 3:17 then probably led Origen to add the words ipse sanctus Spiritus. Thus, the whole phrase is to be translated or paraphrased as follows: 'The Lord Jesus Christ himself, the Holy Spirit himself must be entreated by us'.

By way of answering the question raised above, the Holy Spirit is not supposed to be the sole addressee of the prayers that ask for understanding of the biblical text. Rather, there are two addressees: Jesus Christ and the Holy Spirit. Further, it was not so much the New Testament teaching of the inspiration of Scripture through the Holy Spirit (cf. 2 Pet. 1:21) 35 but rather his quotation from 2 Corinthians 3:16-17 that led Origen to consider the Holy Spirit the addressee of prayers asking for understanding of the biblical text under consideration in the homilies on Leviticus.

According to Hamman, the above statement of Origen is the first express reference to prayer to the Holy Spirit in eastern Christianity. ${ }^{36}$ However, as will become obvious in the next two sections, there are

33 Cf. Origène, Lévitique (tr. Borret), 69, n. 3: 'Ici est omise l'affirmation : 'Car le Seigneur est Esprit. Au début de l'hom. 4, elle sera citée.'

34 English: Origen, Leviticus (tr. Barkley), 70; Latin: Origène, Lévitique (tr. Borret), 162.

35 Adalbert Gautier Hamman, La Prière dans l'Eglise ancienne (Traditio Christiana 7; Berne: Peter Lang, 1989): 65, n. 1: 'L'Esprit qui a inspiré l'Ecriture peut seul en révéler le contenu et la signification. D'où le recours à lui dans la prière.'

36 A. Hamman, Prières des premiers chrétiens (Textes pour l'histoire sacrée; Paris: Librairie Arthème Fayard, 1952): 81, n. 1: 'Nous voyons le rôle important que le SaintEsprit joue dans la théologie et la prière d'Origène. C'est le premier témoin explicite de ce culte, en Orient.' 
two other important eastern witnesses to praying to the Holy Spirit stemming from a slightly earlier time.

\section{Jesus's Hymn and Round Dance (Acts of John 94-96)}

Chapters 94-96 of the second-century apocryphal Acts of John, a work that originated in Egypt, ${ }^{37}$ Asia Minor, ${ }^{38}$ or Syria/Palestine ${ }^{39}$ —narrate a hymn and round dance that Jesus sang/danced with his disciples. Eric Junod and Jean-Daniel Kaestli are convinced that chapters Acts of John 94-102 and 109 do not belong to the original Acts of John..$^{40}$ According to Junod and Kaestli, these chapters are gnostic ${ }^{41}$ and originated in Syria in the Second Century AD. ${ }^{42}$ In her study on the Acts of John, Gerlinde Sirker-Wicklaus does not agree with Junod's and Kaestli's findings ${ }^{43}$ but rather considers the Acts of John a literary whole ${ }^{44}$ that is to be situated not within Gnosticism but rather in the margin of the Catholic Church. ${ }^{45}$ In the framework of the present article it is impossible to further discuss - let alone solve - these scholarly disagreements regarding the origin of chapters Acts of John 94-102 and 109. In each case, Jesus's hymn and round dance narrated in Acts of

37 Eric Junod and Jean-Daniel Kaestli, eds., Acta Iohannis (Corpus Christianorum Series Apocryphorum 1 and 2; Turnhout, Brepols, 1983): 694.

38 Pieter J. Lalleman, The Acts of John: A Two-Stage Initiation into Johannine Gnosticism (Studies on the Apocryphal Acts of the Apostles 4; Leuven: Peeters, 1998): 261-68.

39 Sirker-Wicklaus, Gerlinde, Untersuchungen zu den Johannes-Akten: Untersuchungen zur Struktur, zur theologischen Tendenz und zum kirchengeschichtlichen Hintergrund der Acta Johannis (Beiträge zur Religionsgeschichte; Bd.2; Witterschlick /Bonn : Wehle, 1988): 239.

40 Junod / Kaestli, Acta Iohannis, 425: 'Ceux-ci se distinguent par leur vocabulaire aussi bien que par leur perspective doctrinale. Nous tenons pour sûr qu'ils ne sont pas de la plume de l'auteur des $A J$.'

41 Junod / Kaestli, Acta Iohannis, 627: 'Les caractéristiques que nous venons de dégager ne laissent subsister aucun doute quant à l'origine gnostique d'AJ 94-102 et 109.'

42 Junod / Kaestli, Acta Iohannis, 631-32.

43 Sirker-Wicklaus, Untersuchungen, 227: 'Die Thesen von JUNOD/KAESTLI erscheinen sowohl für sich genommen wie auch in Beziehung zueinander gesetzt nicht schlüssig.'

44 Sirker-Wicklaus, Untersuchungen, 2: 'diese Arbeit [geht] ... in der Auseinandersetzung mit den AJ von einer redaktionellen Einheitlichkeit aus'.

45 Sirker-Wicklaus, Untersuchungen, 240. 
John 94-96 stems from the Second Century AD. In Acts of John 94, the passage relevant for this article reads as follows: ${ }^{46}$

'Now, before he [Jesus] was arrested ... he gathered us all together and said, "Before I am delivered up ... let us sing a hymn to the Father, and go forth to what lies before us." So he commanded us to make a circle, holding one another's hands, and he himself stood in the middle. He said, "Respond Amen to me." He then began to sing a hymn, and to say:

"Glory be to you, Father!"

And we circling him said, "Amen."

"Glory be to you, Word! Glory be to you, Grace!" "Amen."

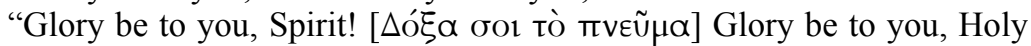

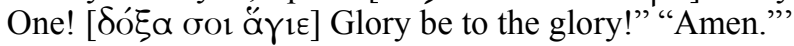

Later in the event, Jesus is commanding his disciples (Acts of John 96): 47

'Say again with me:

Glory be to you, Father;

Glory be to you, Word;

Glory be to you, Holy Ghost!'

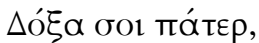

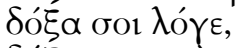

$\delta o ́ \xi \alpha \sigma o 1<\tau o>\pi v \varepsilon \tilde{\mu} \mu \alpha[\ddot{\gamma} \gamma 10 v]$

Scholars disagree as to whether the predicates used in the above quoted doxologies from Acts of John 94 and 96 refer to only one (and thus the same) divine being or to several divine persons. ${ }^{48}$ According to Lipsius, ${ }^{49}$ Sirker-Wicklaus, and Stuart G. Hall, the doxology addresses God the Father, the Son, and the Spirit. Hall states with regard to the doxology in Acts of John 94, 'The form is trinitarian, apparently constructed with one title for the Father, two for the Son, and three for

46 English: J. K. Elliott, ed. The Apocryphal New Testament: A Collection of Apocryphal Christian Literature in an English Tranlation (Oxford: Clarendon, 1993): 318; Greek: Junod / Kaestli, Acta Iohannis, 201.

47 English: Elliott, Apocryphal New Testament, 319; Greek: Junod / Kaestli, Acta Iohannis, vol. 1, 207.

48 Cf. Richard Adelbert Lipsius, Die apokryphen Apostelgeschichten und Apostellegenden, vol. 1 (1883; Reprint Amsterdam: Philo, 1976): 527: 'Die Doxologie [AJ 94] hat dadurch etwas Dunkeles, dass sich schwer entscheiden lässt, ob mit den Prädikaten "Vater", "Logos", "Gnade", "Geist", "Heiliger" ein und dasselbe, oder verschiedene göttliche Subjecte angeredet werden sollen.'

49 Lipsius, Apostelgeschichten, 527. 
the Spirit, though the text for the third limb is not absolutely certain. ${ }^{\prime} 50$ The position that this doxology addresses the Holy Spirit is also taken by Sirker-Wicklaus who writes: 'Der Begriff $\pi$.[veṽ $\mu \alpha]$ findet sich an sieben Stellen in den AJ [Acta Johannis]. Drei von ihnen entfallen dabei auf tò $\pi v \varepsilon \tilde{u} \mu \alpha$ ŏ $\gamma 10 v$ als Person (c. 94, 12; c. 96, 23 und c. 98, 11). ${ }^{51}$ According to other scholars, however, all predicates used in the doxologies of Acts of John 94 and 96 refer to the same divine person, namely Christ. Pieter J. Lalleman states, 'all predicates used hereFather, Grace, Word, Glory, Spirit—ultimately refer to one person ... I conclude that c. 94 is a ... glorification of the polyonymous Christ ... Thus Christ in fact asks the disciples to praise himself.' 52 Junod and Kaestli hold the same position and refer to Acts of John 96, 98, and 109 for evidence: 'tous les noms servent à célébrer un seul être divin, comme le montre clairement le parallèle avec les énumérations des ch. 98 et 109: "Père", "Logos" et "Grâce" s'y retrouvent, appliqués à la Croix de lumière ou à Jésus. Par ailleurs, le Seigneur qui chante l'hymne ne doit pas être distingué du Logos célèbre ici (cf. 96, 6), mais il doit lui-même être glorifié par toute une série de noms. ${ }^{53}$ Raniero Cantalamessa ${ }^{54}$ takes a kind of middle position: on the one hand, Jesus's statement in Acts of John 96 that he has been sent 'as the Word

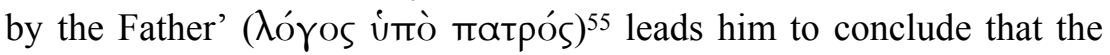
$\lambda$ óros and the Father need to be distinguished from each other and that the doxologies in Acts of John 94 and 96 are thus addressed to several persons. On the other hand, like Junod and Kaestli, Cantalamessa refers to the list of titles for Christ in Acts of John 98 and thus considers the doxological predicates in Acts of John 94 and 96 references to just one person, i.e. Christ, the Father. Cantalamessa then attempts to solve the tension between these contradictory observations by pointing to (1) the

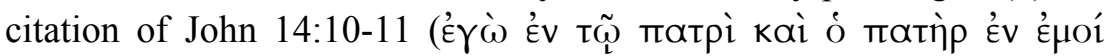
Értv) in Acts of John 100; and (2) the goal of the list of Christological

\footnotetext{
50 Stuart G. Hall, 'Melito's Paschal Homily and the Acts of John', The Journal of Theological Studies, New Series', 17 (1966): 97.

51 Sirker-Wicklaus, Untersuchungen, 67.

52 Lalleman, Acts of John, 180.

53 Junod / Kaestli, Acta Iohannis,646.

54 For the following, cf. Raniero Cantalamessa, 'Il Cristo "Padre" negli scritti del IIIII sec', Rivista di Storia e Letteratura Religiosa 3 (1967): 9-11; I thank Mrs Ilse ten Cate who helped me to read this article.

55 English: Elliott, Apocryphal New Testament, 319; Greek: Junod / Kaestli, Acta Iohannis, 205.
} 
titles (liste di titoli cristologici ${ }^{56}$ ) in Acts of John 109, namely, the exaltation of Christ (all'esaltazione della divinità di Cristo $^{57}$ ). Thus, in the end Cantalamessa seems to tend more towards the position that the doxologies in Acts of John 94 and 96 address only Christ. The reasoning of Cantalamessa and Junod and Kaestli on the basis of Acts of John 98 and 109 is convincing. Therefore, the doxologies in Acts of John 94 and 96 probably use the epithet 'Spirit' (tò $\pi v \in \tilde{u} \mu \alpha$ ) —and the other epithets - to address Jesus Christ. Put differently, they are probably not to be considered prayers to the Holy Spirit even though one cannot totally rule out the Holy Spirit as addressee.

\section{Acts of Thomas}

In chapters 27 and 50, the apocryphal Acts of Thomas contain two prayers that are considered Spirit epicleses by the majority of scholars. ${ }^{58}$ Before turning to these prayers, however, a few introductory remarks regarding the Acts of Thomas are in order. These Acts were probably written in Syria in the early Third Century AD. ${ }^{59}$ The Acts of Thomas are extant in both Syriac and Greek. While Syriac is probably the original language of the work, the Greek version/translation is more faithful to the original content of the Acts of Thomas. Therefore, the present article studies the two prayers in Acts of Thomas 27 and 50 on the basis of the Greek version of the text. ${ }^{60}$ In the English translation of J. K. Elliott, the Greek baptismal prayer of the apostle Judas Thomas in Acts of Thomas 27 reads as follows:

Come, holy name of Christ, which is above every name;

Come, power of the Most High, and perfect compassion;

Come, gift most high;

Come, compassionate mother;

Come, fellowship of the male;

Come, revealer of secret mysteries;

Come, mother of the seven houses, that there may be rest for you in the eighth house.

\footnotetext{
56 Cantalamessa, 'Cristo', 11; cf. on the same page: 'l'accumulamento di titoli diversi sulla persona di Cristo'.

57 Cantalamessa, 'Cristo', 11.

58 Cf. e.g. Kruse, 'Zwei Geist-Epiklesen', 33-53; Myers, Epicleses.

59 Cf. Myers, Epicleses, 29-55.

60 This approach is also taken in Myers, Epicleses, 18.
} 
Come, elder of the five members: intelligence, thought, prudence, reflection, reasoning,

Communicate with these young men!

Come, Holy Spirit, and purify their loins and their hearts,

And seal them in the name of the Father and of the Son and of the Holy Ghost. 61

The last request introduced with 'Come' expressly addresses the 'Holy Spirit' (tò ớ $\gamma 10 v \pi v \varepsilon \tilde{v} \mu \alpha) .{ }^{62}$ This is also the case in the extant Syriac version of Acts of Thomas 27 where the respective line reads as follows: 'come, Spirit of holiness and purify their reins and their hearts'. ${ }^{63}$ In the English translation of Elliott, the Greek eucharistic prayer of the apostle Judas Thomas in Acts of Thomas 50 reads as follows:

Come, perfect compassion;

Come, fellowship with the male;

Come, you who know the mysteries of the Chosen One;

Come, you who have partaken in all the combats of the noble combatant;

Come, rest, that reveals the great deeds of the whole greatness;

Come, you who disclose secrets

And make manifest the mysteries;

Come holy dove,

Who bear the twin young;

Come, secret mother;

Come, you who are manifest in your deeds;

Come, giver of joy

And of rest to those who are united to you;

Come and commune with us in this eucharist,

Which we celebrate in your name,

And in the agape

In which we are united at your calling. ${ }^{64}$

The Syriac version of this prayer expressly addresses the Holy Spirit. The prayer begins as follows: 'Come, gift of the Exalted; come, perfect mercy; come, holy Spirit; come' ${ }^{65}$ However, from the Greek version, an express address of the Holy Spirit is absent. Nevertheless, not only Acts of Thomas 27 but also 50 is commonly considered a Spirit

61 Elliott, Apocryphal New Testament, 458.

62 Maximilianus Bonnet, ed., Acta Philippi et Acta Thomae, Accedunt Acta Barnabae (Acta Apostolorum Apocrypha AAA, II/2; Hildesheim: Georg Olms, 1990): 143.

63 English: W. Wright, ed., Apocryphal Acts of the Apostles: Edited from Syriac Manuscripts in the British Museum and Other Libraries, vol. 2, The English Translation (Piscataway, New Jersey: Gorgias, 2005): 167.

64 Elliott, Apocryphal New Testament, 468.

65 Wright, Apocryphal Acts of the Apostles, vol. 2, 189. 
epiclesis. Susan E. Myers, for instance, argues with regard to the latter text, 'The addressee of the epiclesis over the eucharistic bread is indeed the Spirit. This will become evident by examination of the feminine epithets used in the epiclesis in chapter 50 and in the striking similarity between this prayer and that in chapter 27 , which is clearly addressed to the Spirit.' 66 It can thus be concluded that not only the prayer in Acts of Thomas 27 but also that in 50 is addressed to the Holy Spirit.

However, for the present article it is crucial to ask and answer the question if these prayers are exclusively addressed to the Holy Spirit (i.e. not also to Jesus Christ) or if they are also addressed to Jesus Christ. Scholars are divided regarding this question. Myers, for instance, opts for the view that the Holy Spirit is the sole addressee of Acts of Thomas 27 and 50. ${ }^{67}$ After changing her mind, Gabriele Winkler also takes this position. ${ }^{68}$ On the other hand, Caroline Johnson states with regard to Acts of Thomas 27, 'perhaps this epiclesis is addressed to both Christ and the Holy Spirit'. ${ }^{69}$

In the following, it will be argued that even though Jesus Christ is not expressly mentioned as addressee one should not dismiss Caroline Johnson's above quoted position too quickly. Three arguments are crucial in this regard. First, the following set of arguments that A. F. J. Klijn presents in his seminal commentary on the Syriac Acts of Thomas can equally be applied to the Greek version of the prayers in Acts of Thomas 27 and 50. With regard to the epithet 'power of the Most High', Klijn states that "“[p]ower" is the same as the Holy Spirit, see Luke 24, 49 and Acts 8, 10.9, or even Christ, see I Cor. 1, 24'.70 In the same vein, regarding 'perfect compassion' Klijn points out 'that

\footnotetext{
66 Myers, Epicleses, 148.

67 Myers, Epicleses, 146-52.

68 Gabriele Winkler, 'Weitere Beobachtungen zur frühen Epiklese (den Doxologien und dem Sanctus): Über die Bedeutung der Apokryphen für die Erforschung der Entwicklung der Riten', Oriens Christianus 80 (1996): 196: 'In einer kürzlich erschienenen Arbeit machte ich auf eine Oszillation zwischen dem "Messias" und dem Geist aufmerksam, die typisch für die Frühform der syrischen Epiklesen in den apokryphen Thomasakten sei. Bei genauer Betrachtung der syrischen Texte ist jedoch eine Nuancierung feststellbar: Die Epiklese zur (präbaptismalen) Salbung richtet sich an den Namen des "Gesalbten" (den $M^{e}$ š̄ $\grave{h} \bar{a}$ ), hinter dem sich niemand anderer als die Mutter, der Geist, verbirgt, der (dem) die gesamte Anrufung gilt. Bei der Epiklese zur eucharistischen Mahlfeier wird hingegen die Mutter, der Geist der Heiligkeit, angerufen.'

69 Johnson, 'Epicleses', 192, n. 65.

70 A. F. J. Klijn, The Acts of Thomas: Introduction, Text, and Commentary (Supplements to Novum Testamentum 108; 2nd edn; Leiden: Brill, 2003): 80.
} 
"mercy" can be identified with Christ'. ${ }^{71}$ And on the line 'Come, revealer of secret mysteries' Klijn comments that '[i]n ch. 10 it is said that Christ reveals the mysteries' ${ }^{72}$ Second, the repeated command

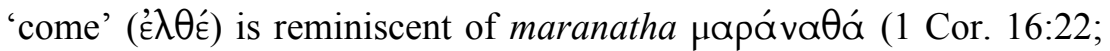

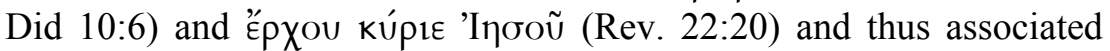
with prayers that are addressed to the Lord Jesus Christ rather than to the Holy Spirit. ${ }^{73}$ Third, the main argument for the exegetical view of the Holy Spirit being the sole addressee of the prayers in Acts of Thomas 27 and 50 is the occurrence of the many feminine epithets in Acts of Thomas 27 and 50. Myers states, 'if the epithets in the epicleses are intended to refer to Jesus, the use of the feminine would then have to be explained. The simplest solution is to see an appeal, originally in a Semitic language, to the Spirit'. ${ }^{74}$ However, Myers - and scholarship in general-did not even attempt to explain how the use of the feminine could correspond with Jesus as potential addressee of the epicleses in Acts of Thomas 27 and 50. That it is very well possible to associate feminine attributes with Jesus will now be demonstrated on the basis of the feminine epithet 'mother' that is used in both Acts of Thomas 27 and 50. In the Gospel of Matthew that-like the Acts of Thomas - probably originated in Syria, ${ }^{75}$ Jesus addresses Jerusalem with the words 'How often would I have gathered your children

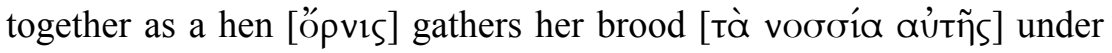
her wings, and you would not!' (Matt. 23:37; cf. Luke 13, 34). From a grammatical point of view, the Greek word opvis can be both masculine and feminine. ${ }^{76}$ However, that Matthew 23:37 has a feminine bird in view is not only suggested by the bird's action ${ }^{77}$ but also by the

71 Klijn, Acts, 80.
72 Klijn, Acts, 81.

73 Cf. however, Kruse, 'Zwei Geist-Epiklesen', 36: After stating that Ezek. 37:9 probably influenced the Spirit epiclesis in Acts of Thomas 27, Kruse denies that the call 'Maranatha' stands in the background of the call 'come' in Acts of Thomas 27: 'Nicht der Maranatha-Ruf, wie bisweilen vermutet wird.'

74 Myers, Epicleses, 150; Cf. Lipsius, Apostelgeschichten, vol. 1, 313: ,Abgesehn von dem "Alten der fünf Glieder" wird überall ... ein weibliches Wesen angeredet. Offenbar ist die Sophia oder die Rūhā d'Qudshā gemeint.'

75 Udo Schnelle, Einleitung in das Neue Testament (6th edn; Göttingen: Vandenhoeck \& Ruprecht, 2007): 264.

76 Frederick William Danker, ed., A Greek-English Lexicon of the New Testament and Other Early Christian Literature (3rd edn; Chicago: University of Chicago, 2000): DBAG, 724.

77 Cf. Alan Hugh McNeile, The Gospel According to St. Matthew: The Greek Text with Introduction, Notes, and Indices (Thornapple Commentaries; Grand Rapids, MI: 
feminine personal pronoun aủtñs. Thus, with regard to Matthew 23:37, David L. Turner correctly speaks of a 'feminine image' ${ }^{78}$. This means that Matthew 23:37 associates feminine attributes with Jesus. ${ }^{79}$

By way of conclusion, the prayers in Acts of Thomas 27 and 50, while certainly being addressed to the Holy Spirit, are possibly also addressed to Jesus Christ. Be that as it may, it is important to emphasise that along with Tertullian's De baptismo 8, Acts of Thomas 27 and 50 testify that the idea and practice ${ }^{80}$ of addressing the Holy Spirit in liturgical prayer existed in early Christianity of the Third Century AD. For the sake of completeness, it should be mentioned that this changed in the Fourth Century AD as Paul Bradshaw writes in The New Westminster Dictionary of Liturgy and Worship (2002):

Very early forms of epiclesis were addressed directly to the Spirit (or sometimes to the Logos) in the imperative: 'Come'. But as trinitarian doctrine was gradually refined in the fourth century, this simple form came to be replaced in eucharistic prayers by one in which God was asked to 'send' the Holy Spirit upon the bread and wine as well as upon the communicants, often with the addition of an explicit request for the bread and wine to be transformed into the body and blood of Christ. ${ }^{81}$

\section{Conclusion}

This article studied praying to the Holy Spirit in early Christianity, with the following results: while the New Testament neither contains prayers to the Holy Spirit nor references to such prayers, later early Christian sources from the Second and Third Centuries AD contain at

Baker, 1980): 342: 'The mother bird is more suitable to the simile than the masc.'; Leon Morris, The Gospel According to Matthew (The Pillar New Testament Commentary; Grand Rapids, MI: Eerdmans, 1992): 591, n. 48: 'What the bird is doing here shows that a hen is meant'; Danker, Lexicon, DBAG, 724 (s.v. ópvis): 'in NT only fem. hen. The action of the mother bird or specif. of the hen as a symbol of protecting care'.

78 David L. Turner, Matthew (Baker Exegetical Commentary on the New Testament; Grand Rapids, MI: Baker Academic, 2008): 561.

79 Cf. Boris Paschke, review of Susan Myers, Epicleses, in Biblische Zeitschrift (forthcoming).

80 Myers, Epicleses, 87: Susan Myers argues that the epicleses in Acts of Thomas 27 and 50 are 'stemming from a similar (liturgical) Sitz im Leben'.

81 Paul Bradshaw, 'Epiclesis', 166; Myers, Epicleses, 177: 'the epicleses in the Acts of Thomas differ even from other Christian liturgical epicleses, since those spoken by the apostle Thomas directly address the Spirit; other epicleses address Christ or the Father and ask that the Spirit might come or be present'. 
the least a few passages that are relevant for the topic. In Tertullian's De oratione 12, spiritus sanctus is envisaged as addressee of Christian prayer. However, it remains unclear if this Latin term refers particularly to the third person of the Trinity or to God in general. In De baptismo 8, Tertullian states that spirit epicleses were components of the baptismal services he was familiar with. At the beginning of his homilies on the book of Leviticus, Origen encourages addressing not only Jesus but also the Holy Spirit in prayers asking for understanding the biblical text (Orig. Hom. Lev. I 1). In Jesus's hymn and round dance (which is found in chapters 94-96 of the Acts of John) it is probably not the Holy Spirit but rather Jesus who is addressed with the epithet 'Spirit'. The Acts of Thomas contain two prayers to the Holy Spirit, namely the spirit epicleses in chapters 27 and 50. However, it is possible that these epicleses not only ask the Holy Spirit but also Jesus Christ to come. In view of these findings, it seems (1) that prayers to the Holy Spirit were very rare in early Christianity; and (2) that the Holy Spirit was adressed either alone (Tertullian De baptismo 8) or together with Jesus Christ (Orig. Hom. Lev. I 1). Finally, early Christian praying to the Holy Spirit certainly deserves more scholarly attention than it has received thus far and future studies will hopefully shed more light on this topic. 